\title{
The Effect of Stool Transplantation on Weight Control in Obese Rats
}

\section{$O$ efeito do transplante de fezes no controle de peso em ratos obesos}

\author{
Cynthia Fontoura Klas ${ }^{10}$ Rebeca Loureiro Rebouças ${ }^{1}$ Géssica de Mattos Diosti ${ }^{10}$ Kader Osman ${ }^{1}$ () \\ Luiz Felipe Paludo Carmona ${ }^{2(0)}$ Luiz Fernando Kubrusly ${ }^{10}$ Camila Moraes Marques ${ }^{3(1)}$
}

${ }^{1}$ Faculdade Evangélica Mackenzie do Paraná, Curitiba, PR, Brazil

2 Department of Pathological Anatomy, Hospital Universitário Evangélico Mackenzie do Paraná, Curitiba, PR, Brazil

${ }^{3}$ Faculdades Pequeno Príncipe, Curitiba, PR, Brazil
Address for correspondence Camila Moraes Marques, Ph.D., Faculdades Pequeno Príncipe, Curitiba, PR, Brasil (e-mail: camilam14@gmail.com).

J Coloproctol 2021;41(1):58-62.

\begin{abstract}
Keywords

- stool transplantation

- obesity

- microbiota

- Wistar rats
\end{abstract}

Introduction Obesity is defined as a multifactorial metabolic syndrome in which there is an excessive number of fat cells within the tissues. It is discussed that intestinal microbiota might have a relevant relation with obesity, since it is relevantly altered in obese patients.

Objectives To assess the effect of stool transplantation (ST) in the condition of obesity and its outcomes in an experimental model of cafeteria diet by analyzing histology and weight gain.

Methods Forty male Wistar rats were randomly assigned to 5 groups: control (CO), control with antibiotics $(C O+A T B)$, obesity $(C A F+A T B)$, stool transplantation (ATB + $\mathrm{ST})$ and obesity with stool transplantation $(\mathrm{CAF}+\mathrm{ATB}+\mathrm{ST})$. During the experiment, obesity induction groups received cafeteria diet, whereas the remaining groups had normal diet ad libitum. After 3 months, daily ST was carried out for 8 weeks by gavage procedure. The animals were euthanized, and the small intestine was harvested for further analysis.

Results It was observed that before starting the ST, the cafeteria and normal diet groups had significant weight difference $(p<0,0001)$. In the comparison between $\mathrm{CAF}+\mathrm{ATB}$ and $\mathrm{CAF}+\mathrm{ATB}+\mathrm{ST}$ during the gavage period, the $\mathrm{CAF}+\mathrm{ATB}+\mathrm{ST}$ group presented lower weight gain $(p=0.0017)$. The histopathological evaluation show that the ATB + ST group did not present intestinal crypt distortion.

Conclusion Cafeteria diet resulted in an expected weight gain. In relation to the ST, it has been shown that the procedure is effective in reducing weekly weight gain. Apparently, there was no induction of disabsortive syndrome in nonobese animals that received ST. received

August 7, 2020

accepted

August 30, 2020
DOI https://doi.org/

10.1055/s-0041-1724068.

ISSN 2237-9363.

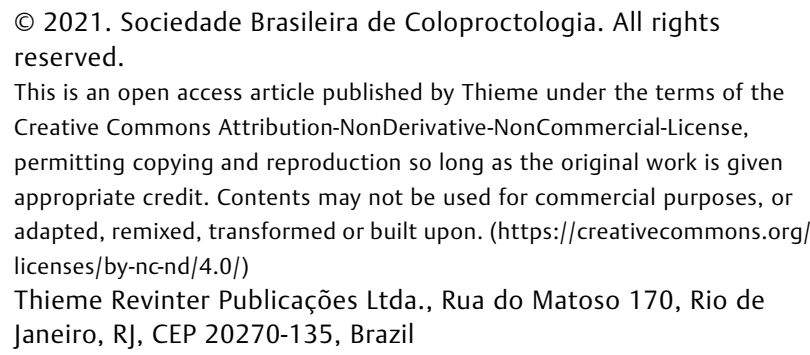

(c) 2021. Sociedade Brasileira de Coloproctologia. All rights reserved.

This is an open access article published by Thieme under the terms of the Creative Commons Attribution-NonDerivative-NonCommercial-License, permitting copying and reproduction so long as the original work is given appropriate credit. Contents may not be used for commercial purposes, or adapted, remixed, transformed or built upon. (https://creativecommons.org/ licenses/by-nc-nd/4.0/)

Thieme Revinter Publicações Ltda., Rua do Matoso 170, Rio de Janeiro, RJ, CEP 20270-135, Brazil 


\section{Resumo}

\author{
Palavras-chave \\ - transplante de fezes \\ - obesidade \\ - microbiota \\ - ratos Wistar
}

Introdução A obesidade é definida como uma síndrome metabólica multifatorial, na qual existe um número excessivo de células de gordura nos tecidos. Discute-se que a microbiota intestinal pode estar relacionada com a obesidade, uma vez que ela é alterada de forma relevante em pacientes obesos.

Objetivos Avaliar o efeito do transplante de fezes (TF) na obesidade induzida por um modelo experimental de dieta de cafeteria.

Métodos Quarenta ratos Wistar foram distribuídos aleatoriamente em 5 grupos: controle (CO), controle com antibióticos (CO + ATB), obesidade (CAF + ATB), transplante de fezes (ATB + TF) e obesidade com transplante de fezes $(C A F+A T B+T F)$. Durante o experimento, os grupos de indução de obesidade receberam dieta de cafeteria, enquanto os demais grupos tiveram dieta ad libitum normal. Após 3 meses, o TF diário foi realizado por 8 semanas por meio de gavagem intragástrica. Os animais foram sacrificados e o intestino delgado foi colhido para análise posterior.

Resultados Observou-se que antes de iniciar o TF, os grupos de dieta de cafeteria e dieta normocalórica apresentavam diferença significativa de peso $(p<0,0001)$. Ao comparar os grupos CAF + ATB e CAF + ATB + TF durante o período de gavagem, o grupo $C A F+A T B+T F$ apresentou menor ganho de peso $(p=0,0017)$. A avaliação histopatológica mostra que nenhum dos animais do grupo TF + ATB apresentou distorções nas criptas intestinais.

Conclusão A dieta da cafeteria resultou em um ganho de peso esperado. Em relação ao TF, demonstrou-se que o procedimento é eficaz na redução do ganho de peso semanal. Aparentemente, não houve indução da síndrome disabsortiva em animais não obesos que receberam TF.

\section{Introduction}

Obesity is a chronic disease currently recognized as a global pandemic and also one of the most alarming public health conditions. It can either be defined as a multifactorial metabolic syndrome or as an excessive accumulation of adipocyte in tissues. ${ }^{1-3}$

According to the World Health Organization (WHO), in 2016, more than 1.9 billion adults were overweight, from whom more than 650 million were classified as obese. ${ }^{4}$

It is currently discussed that the intestinal microbiota might have an intimate relationship with obesity, due to its alterations in obese people. In comparison with lean individuals, obese people present 10 times more bacteria from the group Firmicutes, which, together microorganisms from the Bacteroidetes group, are considered to be among the most important phyla of bacteria in the gastrointestinal tract. ${ }^{5}$

Due to the clinical and social relevance of obesity, and also considering the fact that the treatment of recurrent infection by Clostridium difficile became effective since 1958 using fecal microbiota transplant (FMT), the effectiveness of this treatment brought up the question of whether or not it would be effective to treat other gastrointestinal disorders, such as this relevant disease. ${ }^{6,7}$ A randomized double-blind study showed that FMT from lean to obese individuals resulted in improvement in the insulin sensibility, increase in the microbiota diversity and in the number of butyrate producing bacteria.
Nevertheless, clinical trials to evaluate the efficacy of FMT as a treatment for obesity are still ongoing. ${ }^{8}$

Given this context, it has been questioned if FMT from lean to obese individuals may have any positive effect on weight loss and on the treatment of obesity.

\section{Methodology}

\section{Experimental Design}

The procedures that included animals were in agreement with the one recommended by the Ethical Commission on the Use of Animals (CEUA) of the Faculdade Evangélica Mackenzie do Paraná (FEMPAR), registered under the number 1558/2018.

\section{Animals}

Forty-five-week-old male Wistar rats with an average weight of $300 \mathrm{~g}$, from the central vivarium of the Universidade Federal do Rio Grande do Sul (UFRGS), were used in the research. The animals were kept in the vivarium of FEMPAR in propylene cages of $47 \times 34 \times 18 \mathrm{~cm}$, lined with shavings, in a controlled photoperiod of 12 hours light/dark (light from $7 \mathrm{am}-7 \mathrm{pm}$ ) and room temperature of $22 \pm 2^{\circ} \mathrm{C}$. After 3 weeks of acclimatization with water and appropriate food ad libitum, the rats were identified and placed into separate cages according to the experimental group they were assigned to. 


\section{Experimental Groups}

The rats were distributed in 5 groups with 8 animals each, named:

1. Control (CO) - This group was fed standard commercial feed for 20 weeks.

2. Antibiotic control ( $\mathrm{CO}+\mathrm{ATB})$ - This group was fed standard commercial feed for 20 weeks and received antibiotic for 3 days.

3. Obesity (CAF + ATB) - This group was subjected to obesity induction by the cafeteria diet method and received antibiotic for 3 days.

4. Stool transplant (ATB + ST) - This group was fed standard commercial feed for 20 weeks. Intragastric gavage was performed with feces preparation for 8 weeks, and, 3 days prior to the procedure, the group received antibiotics in the water.

5. Obesity and stool transplantation (CAF $+\mathrm{ATB}+\mathrm{ST})$ This group was subjected to obesity induction by the cafeteria diet method. Intragastric gavage was performed with feces preparation for 8 weeks, and, 3 days prior to the procedure, the group received antibiotics in the water.

\section{Experimental Procedures}

\section{Experimental Model of Obesity}

The model used to induce obesity was the cafeteria (CAF) diet. ${ }^{9}$ Thus, the animals were provided with normal diet ad libitum and a daily selection of grocery foods selected from a list of 16 items (-Table 1), adapted from Almeida et al., 2008. ${ }^{10}$ The feed was changed daily for the animals not to get used to the same food and consequently reject it. There was good acceptance of the CAF diet by the animals, mainly sausage, hamburger, bologna, and wafer.

In addition, the animals had access to two bottles, one containing water and the other containing water with $12 \%$ sucrose, in order to mimic soft drinks. The bottles with water and sucrose were refilled every day until they reached $500 \mathrm{ml}$. The animals ingested about $250 \mathrm{ml}$ of sucrose water per day.

Table 1 Daily breakdown to the cafeteria diet fed to animals

\begin{tabular}{|l|l|}
\hline SUNDAY & $\begin{array}{l}\text { BREAD ROLL, STUFFED BREAD, } \\
\text { MARSHMALLW, BOLOGNA, AND } \\
\text { ANIMAL FOOD }\end{array}$ \\
\hline MONDAY & $\begin{array}{l}\text { WAFER COOKIE, PEANUT CANDY, } \\
\text { SAUSAGE, BROWNIE, AND ANIMAL FOOD }\end{array}$ \\
\hline TUESDAY & $\begin{array}{l}\text { CHEETOS CHEESE, MARSHMALLOW, } \\
\text { HAMBURGER, CANDY BAR, AND } \\
\text { ANIMAL FOOD }\end{array}$ \\
\hline WEDNESDAY & $\begin{array}{l}\text { BREAD ROLL, BOLOGNA, PEANUT CANDY, } \\
\text { WAFER COOKIE, AND ANIMAL FOOD }\end{array}$ \\
\hline THURSDAY & $\begin{array}{l}\text { STUFFED COOKIE, SAUSAGE, CHEESE } \\
\text { CHEETOS, BROWNIE, AND ANIMAL FOOD }\end{array}$ \\
\hline FRIDAY & $\begin{array}{l}\text { BREAD ROLL, BOLOGNA, MARSHMALLOW, } \\
\text { WAFER COOKIE, AND ANIMAL FOOD }\end{array}$ \\
\hline SATURDAY & $\begin{array}{l}\text { BREAD ROLL, BOLOGNA, MARSHMALLOW, } \\
\text { WAFER COOKIE, AND ANIMAL FOOD }\end{array}$ \\
\hline
\end{tabular}

Source: adapted from Almeida et al. (2008).

\section{Stool Transplantation and Vehicle Administration}

The transplant was performed during the last 8 weeks of the experiment. A sample of $200 \mathrm{mg}$ of fresh feces from the control group were collected and mixed with $5 \mathrm{ml}$ of saline solution. A variation of $0.020 \mathrm{~g}$ was accepted between the pieces of feces. The solution was manually stirred and introduced via intragastric gavage in an amount of $200 \mu \mathrm{L}$ per day. ${ }^{11}$ The animals in the control group received water in a volume of $5 \mathrm{ml}$ from the 13th week by intragastric gavage to obtain the same level of stress as the other animals.

Euthanasia and Obtaining Tissue and Blood Samples After 20 weeks of experiment, the animals were weighed and anesthetized with a mixture of xylazine hydrochloride $10 \mathrm{mg} / \mathrm{kg}$ of body weight and ketamine hydrochloride $90 \mathrm{mg} / \mathrm{kg}$ of body weight.

\section{Histological Evaluation}

To perform the histological process, the collected organs were fixated in $10 \%$ formaldehyde dissolved in $0.1 \mathrm{M}$ phosphate buffered saline (PBS); $\mathrm{pH}$ 7.4. Then, fragments of the organs were removed for processing, based on the conventional histological technique, and then included in paraplast, oriented so that the obtained cuts resulted in cross sections, which were stained with hematoxylin \& eosin for the analysis of histopathological changes.

\section{Results}

\section{Preliminary Remarks}

The animals were observed for all 20 weeks of the obesity induction. It was noticed that the animals that received the CAF diet preferred the high-calorie food, consuming the whole amount available, whereas they would leave most of the regular diet aside.

From the 3rd day of the experiment, it was seen that the animals that received the water with sucrose CAF diet drank more water and urinated more than the other groups.

From the 7th week onwards, a greater weight gain was observed in animals with the CAF diet and in the CAF diet group that would later receive $\mathrm{ST}(\mathrm{CAF}+\mathrm{ATB}$ and $\mathrm{CAF}+\mathrm{ATB}$ $+\mathrm{ST}$, respectively). It was also noticed that the animals that received the CAF diet had the highest appetite when compared with the animals that only had regular diet.

There was no change in the animals' behavior in relation to that prior to the beginning of intragastric gavage. It was noticed that there was no increase in stool evacuation or softening in the groups that received the ST (TF + ATB and $\mathrm{CAF}+\mathrm{ATB}+\mathrm{ST}$ ) when compared to the other groups during the 8 weeks in which the gavage was performed.

\section{Body Weight}

For the animal's body weight analysis, a comparison between the average weekly weight gain of the animals before and after the beginning of the gavage was made. In doing so, a statistical difference was noticed between all groups on regular diet and those on high calorie diet. All with $p<0.0001$. Also, no difference was found when comparing 


\section{Graphical 1 - Weekly weight gain before gavage}

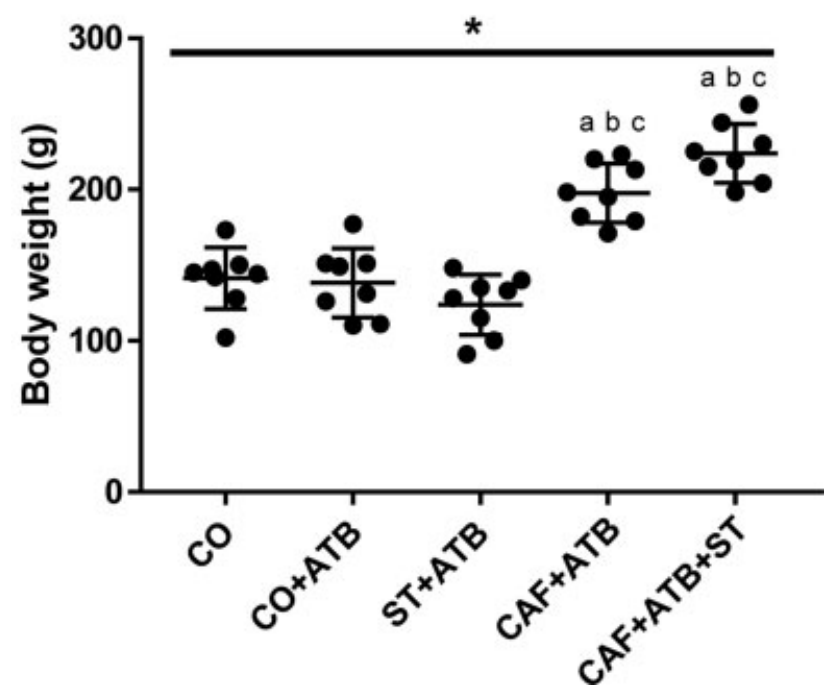

Graphic 1 Weekly weight gain before gavage. Comparative analysis of means between groups using the one-way analysis of variance test $\left(p<0.0001^{*}\right)$. a - statistically different from the CO group, b - statistically different from the CO + ATB group, $c$ - statistically different from the ATB + ST group. * statistically significant values $p<0.05$. Source: The author (2019).

the weights from control groups and the ones who received the CAF diet. (- Graphic $\mathbf{1}$ )

There was no statistical difference regarding the average weekly weight gain after the beginning of gavage between the groups that did not receive the CAF diet (-Graphic $\mathbf{2}$ ). There was also no statistical difference between the groups that did not receive the high-calorie diet in comparison with the group that received ST with regular diet (CO and ATB + ST, $\mathrm{CO}+\mathrm{ATB}$ and ATB $+\mathrm{ST})$. There was also no statistical difference between the groups that underwent ST $(\mathrm{ATB}+\mathrm{ST}$ and $\mathrm{CAF}+\mathrm{ATB}+\mathrm{ST})$. A statistically significant difference was observed between the group that received a CAF diet and the group that received the same diet, and also received ST $(\mathrm{CAF}+\mathrm{ATB}$ and $\mathrm{CAF}+\mathrm{ATB}+\mathrm{ST})$. All with $p<0.0001$.

\section{Histological Analysis}

During the small intestine analysis, it was noticed that $100 \%$ of the animals in the control group remained with the structure of normal intestinal crypts. In the CAF diet group, $75 \%$ of the animals had cryptic hypotrophy, and in the CAF diet group with ST, 50\% (- Table 2).

\section{Discussion}

A study was performed with the decoction of a Chinese herb (Lingguizhugan) associated with caloric restriction in order to investigate weight loss in the rats that followed this diet. It was noticed, however, that when associated with ST, there was a much more significant weight loss. The present study corroborates with ours, and, therefore, allows us to verify that ST was effective to reduce the weight gain in the groups of animals that were submitted to the procedure. Both

\section{Graphical 2 - Weekly weight gain after gavage}

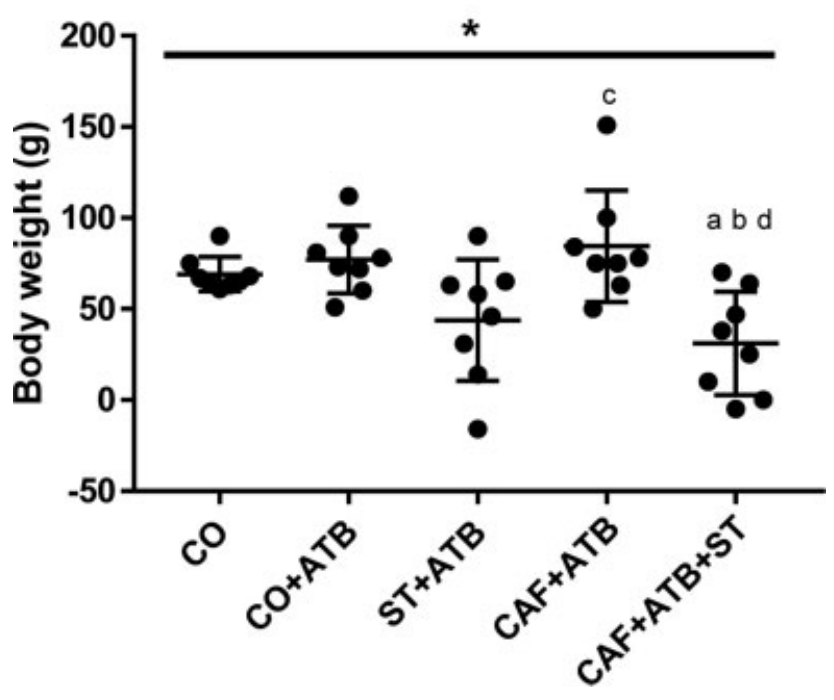

Graphic 2 Weekly weight gain after gavage Comparative analysis of means between groups using the one-way analysis of variance test $\left(p=0.0006^{*}\right)$. a - statistically different from the CO group, b - statistically different from the $\mathrm{CO}+$ ATB group, c - statistically different from the ATB + ST group, $\mathrm{d}$ - statistically different from the CAF + ATB group. * statistically significant values $p<0.05$. Source: The author (2019).

groups of animals that received a high-calorie diet gained weight in the same proportion before the beginning of ST. From the beginning of the procedure in one of the groups, the animals started to gain weight in different proportions, and the group that received ST gained less weight. ${ }^{12}$

In a study in which different groups of rats were submitted to normo and hypocaloric diets, it was found that around the 15th week of life, both groups started to have their weight stabilized. This fact suggests that the reason why it was evident in our study that all groups of animals started to gain less weight after the beginning of gavage, which occurred after the 12th week of the experiment, 16 weeks of the animals' life. ${ }^{13}$

Some of the known acquired causes of intestinal malabsorption are short bowel syndrome, loss of absorptive surface due to inflammatory diseases, and motor disorders. The development of malabsorption due to diseases of the small intestine mucosa depends on the location, severity, and extent of the disease. Symptoms of malabsorption include chronic diarrhea, weight loss, steatorrhea, malnutrition with muscle loss, and anemia. ${ }^{14}$ It was not evident in our study the presence of any of these symptoms in animals that received ST, suggesting that a disabsorptive syndrome was not caused in these animals.

Small intestine biopsies in the context of disabsorptive syndrome are most often used to assess secondary pathologies. ${ }^{14}$ And, despite being useful in the identification of root causes, a biopsy can reveal histologically unspecified findings. ${ }^{15}$ The evaluation of the length and architecture of the intestinal villi, changes in the intestinal crypts and infiltration in the lamina propria can diagnose different types of enteropathy. ${ }^{16}$ In our study, microscopic analysis of the 
Table 2 Presence of crypt distortion in microscopy of the small intestine

\begin{tabular}{|l|l|l|l|l|l|}
\hline $\begin{array}{l}\text { Cryptic } \\
\text { Distortion }\end{array}$ & CO & CO + ATB & TF + ATB & CAF + ATB & CAF + ATB + ST \\
\hline & $\mathbf{n}(\%)$ & $\mathbf{n}(\%)$ & $\mathbf{n}(\%)$ & $\mathbf{n}(\%)$ & $\mathbf{n}(\%)$ \\
\hline Hyperplasia & & $2(25)$ & & & \\
\hline $\begin{array}{l}\text { Normal } \\
\text { Hypoplasia }\end{array}$ & $8(100)$ & $6(75)$ & $8(100)$ & $\begin{array}{l}2(25) \\
6(75)\end{array}$ & $\begin{array}{l}4(50) \\
4(50)\end{array}$ \\
\hline
\end{tabular}

Abbreviations: $C A F+A T B$, obesity; $C A F+A T B+S T$, obesity with stool transplantation; $C O$, control; $C O+A T B$, control with antibiotics; ST + ATB, stool transplantation.

Source: The author (2019).

small intestine showed no changes in the intestinal crypts of non-obese animals that received ST, suggesting that a disabsorptive syndrome was not induced in these animals.

Environmental enteric dysfunction refers to a syndrome composed of inflammation, reduced absorptive capacity, and reduced barrier function of the small intestine. This condition is described as having a main occurrence during childhood and is associated with poor sanitary conditions, intestinal infections, and micronutrient deficiency. ${ }^{17}$ The first descriptions about environmental enteric dysfunction report microscopic changes in the small intestine. Smaller and shorter intestinal villi were observed, leading to a smaller surface for nutrient absorption. Currently, in addition to flattening villi, crypt hyperplasia and lymphocytic infiltrate in the lamina propria are mentioned. However, these findings are not specific to this disease. ${ }^{17}$ In our study, animals that received STs did not show changes in the intestinal crypts. This suggests that, in the experiment, an environmental enteric dysfunction was not induced in our animals, impairing the intestinal functioning of the groups that received the $\mathrm{ST}$.

\section{Conclusion}

The CAF diet led to increased weight in the animals. Regarding ST, it was found that it was effective in reducing the weekly weight gain in obese animals. Apparently, there was no induction of disabsortive syndrome in non-obese animals that received ST. Further studies are needed to confirm the real effect of ST in obesity.

\section{Conflict of Interests}

The authors have no conflict of interests to declare.

\section{References}

1 James PT, Leach R, Kalamara E, Shayeghi M, Philip T, Leach R, et al. HIServlet_SLET $=A t t V i e w \& A P P=1 \& I D=0000020 \mathrm{rj} \& S E Q=0 \& \mathrm{~K}=00$ 5Bd2j1t\&FILENAME=비 만기준_S228.pdf 20019

2 Bernhard F, Landgraf K, Klöting N, et al. Functional relevance of genes implicated by obesity genome-wide association study signals for human adipocyte biology. Diabetologia 2013;56(02): 311-322. Doi: 10.1007/s00125-012-2773-0

3 Popkin BM, Doak CM. The obesity epidemic is a worldwide phenomenon. Nutr Rev 1998;56(4 Pt 1):106-114
4 Waxman A. WHO's global strategy on diet, physical activity and health: Response to a worldwide epidemic of non-communicable diseases. Scand J Nutr 2004;48:58-60. Doi: 10.1080/110264804 10033539

5 Fujimura KE, Slusher NA, Cabana MD, Lynch SV. Role of the gut microbiota in defining human health. Expert Rev Anti Infect Ther 2010;8(04):435-454. Doi: 10.1586/eri.10.14

6 Smits LP, Bouter KEC, de Vos WM, Borody TJ, Nieuwdorp M. Therapeutic potential of fecal microbiota transplantation. Gastroenterology 2013;145(05):946-953. Doi: 10.1053/j.gastro.2013. 08.058

7 Li M, Liang P, Li Z, et al. Fecal microbiota transplantation and bacterial consortium transplantation have comparable effects on the re-establishment of mucosal barrier function in mice with intestinal dysbiosis. Front Microbiol 2015;6:692. Doi: 10.3389/ fmicb.2015.00692

8 Vrieze A, Van Nood E, Holleman F, et al. Transfer of intestinal microbiota from lean donors increases insulin sensitivity in individuals with metabolic syndrome. Gastroenterology 2012; 143(04):913-6.e7. Doi: 10.1053/j.gastro.2012.06.031

9 Gómez-Gutiérrez A, Miralles MJ, Corbella I, García S, Navarro S, Llebaria X. La calidad sanitaria del agua de consumo. Gac Sanit 2016;30(Suppl 1):63-68. Doi: 10.1016/j.gaceta.2016.04.012

10 Almeida FN, Almeida KN, Masi LN, Nachbar RT, Natali MRM, Moraes SMF. A resposta do peso e da composição corporal à inclusão da dieta de cafeteria e treinamento físico aeróbio em diferentes fases do desenvolvimento. Ciência Cuid e Saúde 2008; 7:39-44. Doi: 10.4025/cienccuidsaude.v7i0.6558

11 Zhou D, Pan Q Shen F, et al. Total fecal microbiota transplantation alleviates high-fat diet-induced steatohepatitis in mice via beneficial regulation of gut microbiota. Sci Rep 2017;7(01):1529. Doi: 10.1038/s41598-017-01751-y

12 Liu MT, Huang YJ, Zhang TY, Tan LB, Lu XF, Qin J. Lingguizhugan decoction attenuates diet-induced obesity and hepatosteatosis via gut microbiota. World J Gastroenterol 2019;25(27):3590-3606. Doi: 10.3748/wjg.v25.i27.3590

13 Porto SMMDS, Viana MT, Da Silva KMF, Diniz MDFA, De Castro CMMB. Neonatal malnutrition and normal microbiota of the oral cavity in rats. Rev Nutr 2007;20:625-632. Doi: 10.1590/S141552732007000600005

14 van der Heide F. Acquired causes of intestinal malabsorption. Best Pract Res Clin Gastroenterol 2016;30(02):213-224. Doi: 10.1016/ j.bpg.2016.03.001

15 Clark R, Johnson R. Malabsorption Syndromes. Nurs Clin North Am 2018;53(03):361-374. Doi: 10.1016/j.cnur.2018.05.001

16 Nikaki K, Gupte GL. Assessment of intestinal malabsorption. Best Pract Res Clin Gastroenterol 2016;30(02):225-235. Doi: 10.1016/ j.bpg.2016.03.003

17 Crane RJ, Jones KDJ, Berkley JA. Environmental enteric dysfunction: an overview. Food Nutr Bull 2015;36(1, Suppl):S76-S87. Doi: $10.1177 / 15648265150361 S 113$ 